\title{
THE CARDIOVASCULAR EFFECTS OF PANCURONIUM BROMIDE DURING HALOTHANE ANAESTHESIA ${ }^{\circ}$
}

\author{
Morris GERTEL, M.D., F.R.C.P. (c)., Gordon S. Fox, M,D, F.R.C.P.(c), \\ Fred I. Rabow, M.D., and Douglas H. Graham, M.D. $\dagger$
}

PANGURONUM BROMIDE, a non-depolarizing neuromuscular blocking agent, has undergone extensive clinical evaluation. ${ }^{1-4}$ To date the only study assessing the effect of pancuronium on the cardiac ontput of anaesthetized patients was published by Kelman and Kennedy. "They demonstrated an increase in cardiac output, heart rate and mean arterial blood pressure in patients anaesthetized with nitrous oxide, oxygen and phenoperidine. This study concerns the cardiovascular effects of pancuronium in patients given nitrous oxide, oxygen and halothane.

\section{METHOD}

Ten patients were studied pre-operatively and after induction of anaesthesia. The majority were in the poor risk category (Table $I$ ). One hundred milligrams of pentobarbitone were given intramuscularly 90 minutes prior to anaesthesia, followed 30 minutes later by meperidine 25 to $100 \mathrm{mg}$ and atropine sulphate $0.4 \mathrm{mg}$ also given intramuscularly. Electrocardiograph lead II was monitorcd in all patients. An intravenous infusion was established and a central venous catheter was inserted for pressure recording. Percutaneous cannulation of a radial artery with a \# 18 teflon catheter was done under local anaesthesia. This cannula was connected to a Statham number $\mathrm{P} 23 \mathrm{Db}$ transducer for direct arterial pressure monitoring. The volume of intravenous infusion was kept to a minimum.

Anaesthesia was induced with 2.5 per cent thiopentone $(200$ to $500 \mathrm{mg}$ ) intravenously. Tracheal intubation was accomplished after the intravenous injection of succinylcholine. Anaesthesia was maintained with nitrous oxide:oxygen ( $4: 2$ litres) and 0.5 per cent halothane in a semi-closed circle system with carbon dioxide absorption. After 20 minutes of mechanical ventilation, and when heart rate and blood pressure were stabilized, central venous pressure, heart rate, systolic and diastolic blood pressure were recorded as control measurements. Control cardiac output was measured in duplicate. Cardiac output was determined by the dye dilution technique, using indocyanine green with a VVaters XC-302 cuvette, a Waters D-400 densitometer and a Honeywell 10-inch recorder (Electrontk 194). The curves were analyzed by the semi-Jogarithmic replot technique. Six mg of pancuronium bromide were injected intravenously as soon as all control mensurements were made. The same variables were again recorded at two, five and ten

"Presented, in part, at the Canadian Anaesthetists' Society Meeting in Halifax, Nova Scotin, June, 1972.

tDepartments of Anaesthesia, Royal Victoria Hospital \& MeGill University, Montreal Canadr.

599

Canad. Anaesth. Soc. J., vol. 19, no, 6, November 1972 


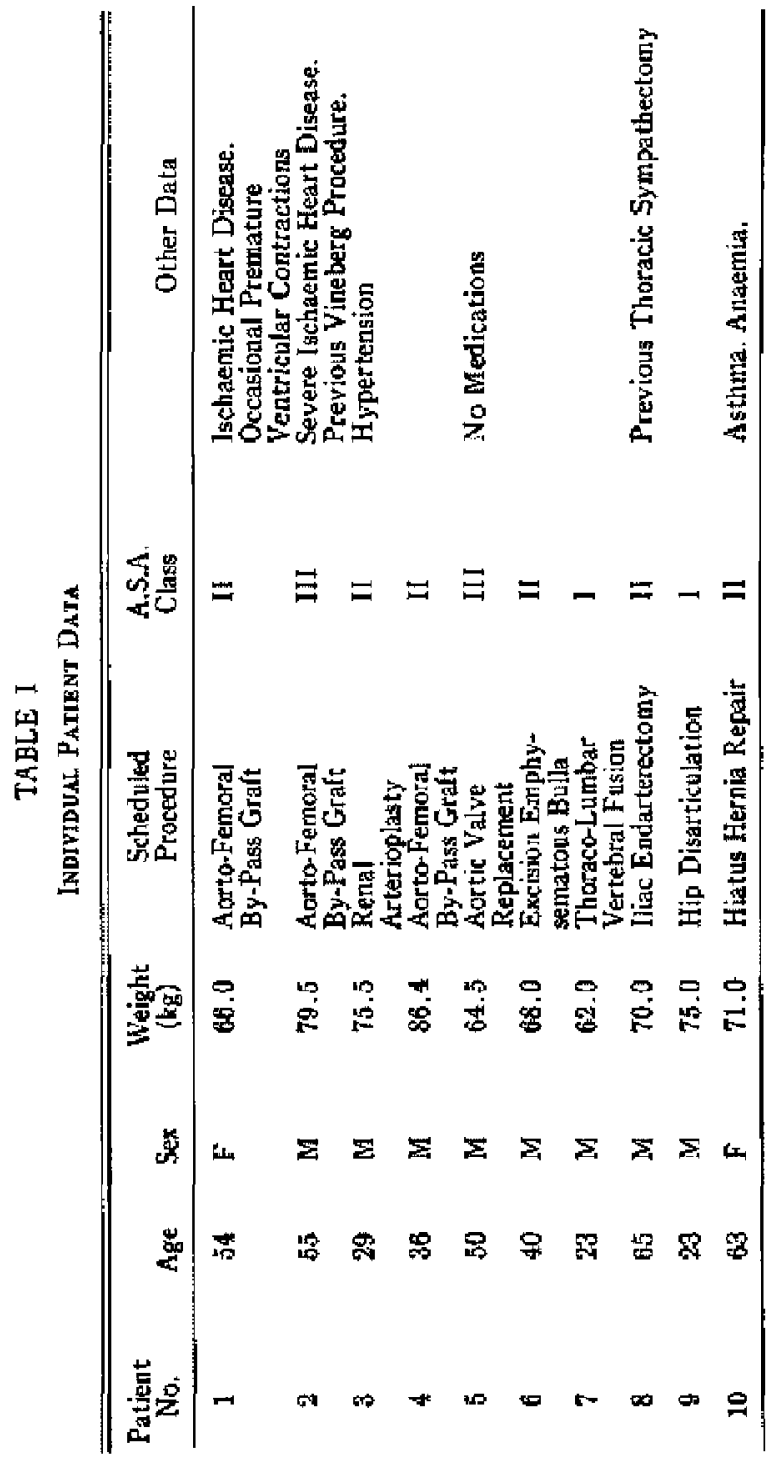


GERTEL, et al.: CARDIOVASCULAR EFFECTS OF PANCUHONIUM

TABLE II

Cardiac Output L/Min

Cardiac output Data: THE CARDIAC OUTPUT INCREASED DURING THE TEN MINUTE PERIOD FOLLOWING INJECTION OF PANCURONIUM $(\mathrm{F}=14.26, \mathrm{~d}$.f. $=1,36 ; \mathrm{p}<.001)$.

\begin{tabular}{cccccc}
\hline Patient & Mean Control & 2 Minutes & 5 Minutes & 10 Minutes & $\begin{array}{c}\text { PaCO2 } \\
\text { (torr) }\end{array}$ \\
\hline 1 & 5.25 & 4.4 & 3.85 & 4.05 & 26.9 \\
2 & 4.45 & 5.3 & 5.35 & 4.25 & 38.5 \\
3 & 4.35 & 9.5 & 9.1 & 8.3 & 56.0 \\
4 & 4.05 & 5.1 & 4.5 & 4.5 & 29.0 \\
5 & 3.3 & 3.6 & 4.8 & 3.8 & 32.0 \\
6 & 3.97 & 6.3 & 5.8 & 5.25 & 41.0 \\
7 & 3.22 & 3.68 & 4.34 & 4.03 & 30.0 \\
8 & 3.3 & 3.38 & 3.27 & 3.36 & 33.0 \\
9 & 6.55 & 6.49 & 6.20 & 6.04 & 79.0 \\
10 & 2.92 & 3.49 & 3.53 & 3.82 & 38.5 \\
\hline
\end{tabular}

minutes after the administration of the muscle relaxant. A sample of arterial blood for gas analysis" was obtained between the five- and ten-minute measurements.

Mean arterial blood pressure (MABP) was calculated using the equation:

$$
\mathrm{MABP}=\frac{2 \mathrm{Pd}+\mathrm{Ps}}{3}
$$

where $P$ s and Pd are systolic and diastolic pressures respectively.

Total peripheral resistance (TPR) was derived in the following manner:

$$
\mathrm{TPR}=\frac{\mathrm{MABP}(\text { torr })-\mathrm{CVP}(\text { torr })}{\mathrm{CO}(1 / \mathrm{min})} \times 79.8 \mathrm{dynes} \mathrm{sec} \mathrm{cm}^{+5}
$$

where $\mathrm{CO}=$ cardiac output and CVP $=$ central venous pressure. The cardiac output measurements before and after administration of pancuronium were compared using a standard two-way factorial analysis of variance, carried out by BMD programme $02 \mathrm{~V}$.

\section{Results}

No cardiac arrhythmias were observed in relation to the administration of pancuronium or the induction of anaesthesia. Cardiac output increased significantly, relative to control, during the ten-minute study period (see Table II). The per cent changes in cardiac output at 2,5 , and 10 minutes after injection of pancuronium are shown in Figure 1. Eight patients showed an increase in cardiac output at 2 minutes, while two patients showed a decrease. At 5 minutes, seven patients exhibited an increase in cardiac output, one patient a negligible change, and two a decrease. Seven patients had an increased cardiac output, while three patients had a decrease in this parameter at 10 minutes. The mean changes at 2,5 , and 10 minutes were +24.9 per cent, +25.4 per cent, and +17.1 per cent respectively.

Mean arterial blood pressure (MABP) showed an average percentage change of +6.5 , +6.4 , and +3.8 , at 2,5 , and 10 minutes respectively (Table III). Heart

"An Instrumentation Laboratories model 113 machine was used for this analysis. 


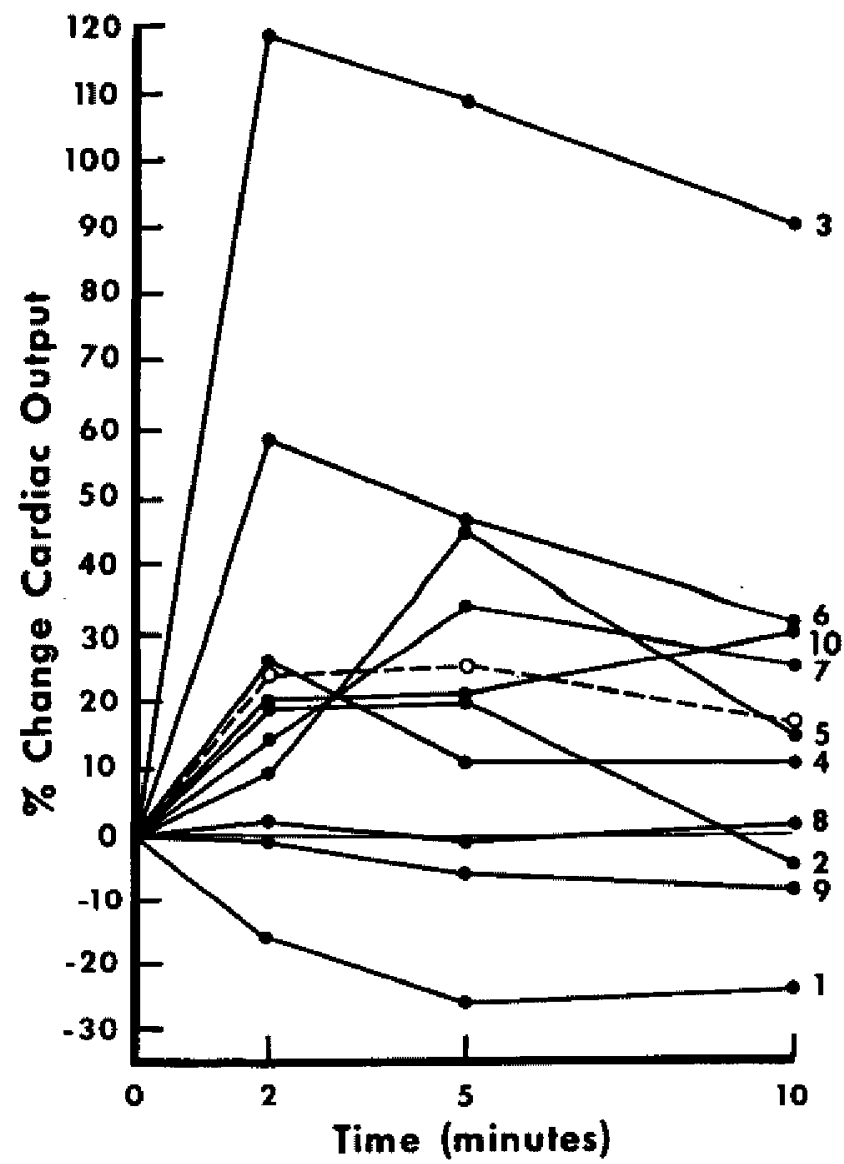

Figure 1. Percentage change in cardiac output for each patient. Open circles represent mean values.

TABLE III

Mean Arteriat. Blood Pressure Percent Change From Control

\begin{tabular}{cccc}
\hline \hline Patient & 2 Minutes & 5 Minutes & 10 Minutes \\
\hline 1 & -4.1 & +2.1 & -14.6 \\
2 & +1.9 & +3.6 & +1.8 \\
3 & +21.6 & +16.7 & +11.1 \\
4 & +22.5 & +22.5 & +30.2 \\
5 & -2.6 & 0 & +5.1 \\
6 & +8.6 & +6.5 & -2.2 \\
7 & +13.8 & +13.8 & +11.2 \\
8 & +3.2 & -0.8 & -5.1 \\
9 & -5.1 & -2.5 & -1.5 \\
10 & +4.7 & +2.4 & +2.4 \\
Mean & $+6.5 \%$ & $+6.4 \%$ & $+3.8 \%$ \\
\hline
\end{tabular}


TABLE IV

Heart Rate - Percent Change From Contror.

\begin{tabular}{cccc}
\hline \hline Patient & 2 Minutes & 5 Minutes & 10 Minutes \\
\hline 1 & 0 & 0 & 0 \\
2 & +23.0 & +15.8 & +15.8 \\
3 & +37.1 & +37.1 & +37.1 \\
4 & +20.0 & +20.0 & +20.0 \\
5 & +33.3 & 0 & +33.3 \\
6 & +41.1 & +35.2 & +29.4 \\
7 & +28.6 & +28.6 & +31.4 \\
8 & 0 & +6.7 & +6.7 \\
9 & 0 & +12.5 & +12.5 \\
10 & +33.3 & +16.7 & +16.7 \\
Mean & +21.6 & +17.2 & +20.3 \\
\hline
\end{tabular}

TABLE $V$

Central Venous Pressure Percent Change FROM CONTROL

\begin{tabular}{cccc}
\hline \hline Patient & 2 Minutes & 5 Minutes & 10 Minutes \\
\hline 1 & -17.4 & -20.6 & -26.4 \\
2 & -7.2 & -20.0 & -20.0 \\
3 & -4.0 & -11.0 & -19.0 \\
4 & -6.8 & -10.7 & -10.7 \\
5 & -18.6 & -30.6 & -51.0 \\
6 & -35.9 & -52.0 & -50.5 \\
7 & 0 & -4.5 & -9.1 \\
8 & 0 & -10.6 & -16.7 \\
9 & -4.3 & -5.3 & -2.1 \\
10 & +15.4 & +11.9 & +11.9 \\
Mean & -7.9 & -15.3 & -19.4 \\
\hline
\end{tabular}

rate was consistently increased relative to control at each study period (Table IV). There was a consistent and progressive fall in central venous pressure (Table V). Stroke volume and total peripheral resistance exhibited a wide variation as detailed in Tables VI and VII respectively.

\section{Discusston}

The commonly used long-acting muscle relaxant available to North American physicians is d-tubocurarine. This agent is known to cause hypotension. Furthermore the combination of curare with halothane is particularly depressant to the cardiovascular system..$^{n, 7}$ In the poor risk patient the maintenance of both blood pressure and cardiac output is of primary importance. In our group of patients mean arterial blood pressure was unchanged or slightly elevated within the tenminute study period. The salient finding of this study is the statistically significant increase in cardiac output with injection of pancuronium during halothane anaesthesia. The average increase in cardiac output of over 20 per cent would appear to be due to the rise in heart rate. The arterial blood pressure was maintained by adequate cardiac output, while total peripheral resistance showed a tendency to decrease indicating adequate or improved peripheral tissue perfusion. 
TABLE VI

Stroke Volume - Percent Change From Control

\begin{tabular}{cccc}
\hline \hline Patient & 2 Minutes & 5 Minutes & 10 Minutes \\
\hline 1 & -16.1 & -26.8 & -23.0 \\
2 & -3.1 & +4.5 & -17.2 \\
3 & +58.6 & +52.0 & +39.2 \\
4 & +6.7 & -8.3 & -8.3 \\
5 & -18.4 & +45.7 & -13.5 \\
6 & +12.1 & +7.9 & +2.1 \\
7 & -11.0 & +4.9 & -4.5 \\
8 & +2.5 & -7.1 & -4.6 \\
9 & -1.1 & -16.1 & -18.2 \\
10 & -10.2 & +3.4 & +11.9 \\
\hline
\end{tabular}

TABLE VII

Total Peripheral Registance Percent Change FroM CONTROL

\begin{tabular}{cccc}
\hline Patient & 2 Minutes & 5 Minutes & 10 Minutes \\
\hline 1 & +17.8 & +46.3 & +13.8 \\
2 & -10.9 & -12.5 & +8.0 \\
3 & -43.0 & -43.0 & -90.0 \\
4 & +3.0 & +17.3 & +25.7 \\
5 & -9.2 & -29.2 & -3.9 \\
6 & -24.9 & -18.4 & -17.8 \\
7 & -6.7 & -15.4 & -11.0 \\
8 & +1.0 & +1.0 & -5.9 \\
9 & -4.3 & +3.4 & +6.8 \\
10 & -13.8 & -16.5 & -22.8 \\
\hline
\end{tabular}

No attempt was made to maintain all the patients in this series at the same $\mathrm{PaCO}_{2} ;$ however, each patient was ventilated for a sufficient period of time to attain a constant $\mathrm{PaCO}_{2}{ }^{8}{ }^{8}$ The range of $\mathrm{PaCO}_{2}$ at twenty-five minutes after initiation of mechanical ventilation was 26.9 to 58 torr (Table II). It has been shown that in patients anaesthetized with halothane cardiac output is directly related to arterial $\mathrm{CO}_{2}$ tension. ${ }^{\mathrm{n}} 10$ However, at any maintained $\mathrm{PaCO}_{2}$ cardiac output remains stable, provided other influencing factors do not change. Changes of cardiac output from control in any given patient were therefore due to the addition of pancuronium to the anaesthetic method. We have shown that cardiac output increases after the injection of pancuronium; nevertheless the range of response is wide (Table II and Figure 1). Arterial carbon dioxide tension greatly influences sympathetic reactivity which secondarily affects cardiac ontput, ${ }^{10}$ the variability of responses which we noted may be related to the various levels of arterial $\mathrm{CO}_{2}$ tension at which our patients were maintained. The data (Table II) suggests that a direct relationship exists between the $\mathrm{PaCO}_{2}$ and the magnitude of change in cardiac output after the administration of pancuronium. The single exception to this trend is patient number nine.

The action of pancuronium on the heart is probably vagolytic. ${ }^{5.11}$ The effect of the drug on cardiac output may also be related to the prevailing sympathtic tone, as set by the $\mathrm{PaCO}_{2}$. 
The choice of a standard dose of $6 \mathrm{mg}$ of pancuronium was based on our own experience with over 150 cases, which verified that this dose provides sufficient muscle relaxation for early maintenance of optimal surgical conditions.

\section{CONCLUSION}

We have demonstrated that pancuronium bromide is compatible with nitrous oxide-halothane anaesthesia in maintaining cardiovascular stability in the poor risk patient.

\section{SUMMARY}

Ten patients were given $6 \mathrm{mg}$ of pancuronium bromide intravenously, after a 20-minute period of mechanical ventilation with nitrous oxide:oxygen $(4: 2)$ and 0.5 per cent halothane. Cardiac output, mean arterial blood pressure, heart rate, central venous pressure, stroke volume, and total peripheral resistance were measured prior to administration and at 2,5 , and 10 minutes after injection of the drug. Cardiac output was increased relative to control during the post-injection study period ( $\mathrm{p}<0.001$ ). On the average, heart rate increased, central venous pressure fell and mean arterial blood pressure rose slightly. Stroke volume and total peripheral resistance showed a variable response. We conclude that pancuronium bromide is compatible with nitrous oxide-halothane anaesthesia with respect to stability of the cardiovascular system.

\section{Résumé}

Après une période de 20 minutes de ventilation mécanique avec du protoxyde d'azote-oxygène $(4: 2)$ et 0.5 pour cent d'halothane, nous avons donné à dix malades, par voie endoveineuse, $6 \mathrm{mgs}$ de bromure de pancuronium; avant l'injection, 2,5 et 10 minutes après linjection de la substance, nous avons mesuré le débit cardiaque, la pression artérielle moyenne, la fréquence cardiaque, la pression veineuse centrale, le volume systolique et la résistance périphérique totale. Comparé au contrôle, le débit cardiaque a augmenté durant la période qui a suivi l'injection $(\mathrm{p}<0,001)$. En somme, la fréquence cardiaque a augmenté; la pression veineuse centrale a baissé et la pression artérielle moyenne s'est élevée légèrement. Le volume systolique et la résistance périphérique totale ont présenté des réponses variables. Nous en venons à la conclusion que le bromure de pancuronium est compatible avec l'anesthésie au protoxyde d'azote/halothane en ce qui concerne la stabilité du système cardiovasculaire.

\section{ACKNOWLEDGMENT}

We wish to thank Organon Inc, Montreal, for a grant-in-aid, and generous supplies of pancuronium bromide (Pavulon ${ }^{\mathbb{E}}$ ) and F.D.K. Liddell, Associate Professor, Department of Epidemiology and Health, at McGill University, for assistance in statistical analysis of our data. 


\section{REFERENCES}

1. KAtz, R.L. Clinical neuronuscular pharmacology of pancuronium. Anesthesiology. $34: 550$ (1971).

2. Vourc' H, G., LecharnY, B. \& Madre, F. Le bromure de pancuronium, nouvel agent curafisant. Anesth. Anal. Réan. 28:1 (1971).

3. PACE-Frondora, A. \& Trop, D. The use of pancuronium bromide - a steroidal neuromuscular blocking agent in prolonged operations. Anesth. \& Analg. 50;987 (1971).

4. Donkin, A,B. Evers, W. ef al. Pancuronium bromide (Pavulon(9), evaluation of its clinical pharmacology. Canad. Anaesth. Soc. J. 18: 512 (1971).

5. Kelman, G.R. \& KenNedy, B.R. Cardiovascular effects of pancuronium in man, Brit. J. Anatesth, 43: 335 (1971).

6. SMTTH, N.T. \& WHrTcren, C.E. Hemodynamic effects of gallamine and tubocurarine administered during halothane anaesthesia. JAMA, 199: 704 (1967).

7. Nieri, R.S. Nixon, B.A. Halothane and tubocurarine: a study of changes in blood pressure. Anaesthesia 20:250 (1965).

8. NunN, J.F. Applied respiratory physiology with special reference to anaesthesia. London: Butterworths (1969),

9. Prys-Ronerts, C., Kelman, G.R., Kain, M.L., Greenfatm, R, \& Bay, J. Cardinc output and blood carbon dioxide levels during halothane anaesthesia in man. Brit. J. Anaesth. 39; 687 (1967).

10. Theye, R.A., MLDE, J.H., \& Michenfelofe, J.D. Effect of hypocapnia on cardiac output during anesthesia. Anesthesiology $27: 778$ (1966).

11. SAXENA, P.R. \& BONTA, I.L. Mechanism of selective cardiac vagolytic action of pancuronium bromide. Specific blockade of cardiac muscarinic receptors. European J. Pharmacol, 11; $332(1970)$. 